\title{
OISTRIBUTION
}

Copy

No.

RECORDS ADMINISTRATION

1-3. J. M. Bauer, DOE-SR

4. N. J. Letang

5. F. E. Kruesi - J. F. Proctor

6. R. E. Naylor

7. W File

8. C. C. Ballard, Eng Dept

9. T. Hendricks

10. H. J. Groh

11. J. L. Womack

12. S. Mirshak

13. S. D. Harris

14. D. L. McIntosh

15. M. L. Hyder

16. R. M. Wallace

17. A. S. Jennings

18. G. W. Wilds

19. J. R. Wiley

20. J. L. Bates (PNL)

21. TIS Record Copy

22-47. TIS File Copies

48-309. DOE-TIC (for distribution under TID-4500 Category UC-70) 


\section{ELECTRICAL RESISTIVITIES OF GLASS MELTS CONTAINING SIMULATED SRP WASTE SLUDGES}

This addendum corrects the resistivities given in DP- 1488 (issued $8 / 78$ ) for Frit 21 glass melts. The experimental data in DP-1488 are corrected in this addendum for the resistance that is developed at high temperatures by the platinum wires in the resistivity probe (Table 1). Earlier treatments of the resistivity data erronenously assumed that this correction was unimportant. However, for the more conductive melts, the reported resistivities were reduced by about $50 \%$ at $1150^{\circ} \mathrm{C}$ and about $10 \%$ at $800^{\circ} \mathrm{C}$. Corrected curves for Frit 18 melts are not included in this addendum because this frit is no longer being considered for solidifying Savannah River Plant waste. Probe resistivities in Table 1 can be used to correct the Frit 18 curves in DP-1488. A resistivity curve for Frit $411^{*}$, the newest candidate frit for solidifying waste sludge, is included in this addendum. Frit 411 was not discussed in DP-1488.

TABLE 1

\begin{tabular}{ll}
$\begin{array}{l}\text { Resistivity of Probe Used in SRL Measurements } \\
\text { Temperature, } \\
{ }^{\circ} \mathrm{C}\end{array}$ & $\begin{array}{l}\text { Resistivity, } \\
\text { ohm-cm }\end{array}$ \\
\hline 1200 & 3.6 \\
1150 & 3.5 \\
1100 & 3.4 \\
1050 & 3.3 \\
1000 & 3.3 \\
923 & 3.2 \\
884 & 3.2 \\
844 & 3.1 \\
804 & 3.0 \\
763 & 2.8
\end{tabular}

₹ The composition of Frit 411 is $\mathrm{SiO}_{2}, 58.3$; $\mathrm{Na}_{2} \mathrm{O}, 12.5$; $\mathrm{B}_{2} \mathrm{O}_{3}, 11.1 ; \mathrm{CaO}, 5.6, \mathrm{Li}_{2} \mathrm{O}, 12.5 \mathrm{wt} \%$. 
The description of the effects of waste components on resist1vity that is given in DP-1488 is unchanged because subtracting the probe resistance from the original data does not affect the ordering of the corrected curves (F1gures 1-4). Correlations between resistivity and viscosity are also essentially unchanged. Ordinates (resistivities) in Figures 12 and 13 (in DP-1488) would change with the corrected values, and slopes of the lines in the figures would change slightly.

To facflitate comparing the corrected resistivities with previously published melt viscosities, the experimental data shown in Figure 1-4 were fit to the same function used to fit the viscosity data. 1

$$
\ln \rho=A+\frac{B}{T-T_{0}}
$$

Expanding the last term leads to the polynominal form used in DP-1488. Coefficients to Fit Equation 1 to data in Figures 1-4 are 11sted in Table 2 .

TABLE 2

Constants for Fitting Resistivity Curves of Frit 21 Glasses

$$
\text { ln } \left.\rho=A+B / T-T_{0}\right)\left(\rho \text { in ohm-cm, } T \text { in }{ }^{\circ} \mathrm{K}\right)
$$

\begin{tabular}{|c|c|c|c|c|}
\hline Sludge & $\begin{array}{l}\text { Amount, } \\
\text { wt \% }\end{array}$ & A & $\underline{B}$ & $\underline{T}_{0}$ \\
\hline Composite & $\begin{array}{l}25 \\
30 \\
35\end{array}$ & $\begin{array}{l}-5.84 \\
-5.93 \\
-6.06\end{array}$ & $\begin{array}{r}8545 \\
9610 \\
10559\end{array}$ & $\begin{array}{r}202 \\
96.9 \\
14.3\end{array}$ \\
\hline Average & $\begin{array}{l}25 \\
35\end{array}$ & $\begin{array}{l}-3.02 \\
-2.92\end{array}$ & $\begin{array}{l}4054 \\
3470\end{array}$ & $\begin{array}{l}431 \\
538\end{array}$ \\
\hline $\mathrm{High} \mathrm{Fe}$ & $\begin{array}{l}25 \\
35\end{array}$ & $\begin{array}{l}-2.97 \\
-3.09\end{array}$ & $\begin{array}{l}3644 \\
3539\end{array}$ & $\begin{array}{l}545 \\
539\end{array}$ \\
\hline $\mathrm{High} \mathrm{Al}$ & $\begin{array}{l}25 \\
35\end{array}$ & $\begin{array}{l}-2.97 \\
-3.63\end{array}$ & $\begin{array}{l}4078 \\
4678\end{array}$ & $\begin{array}{l}480 \\
480\end{array}$ \\
\hline Pure Frit 21 & - & -1.60 & 2132 & 577 \\
\hline
\end{tabular}

1. M. J. Plodinec. Viscosity of Glasses Containing Simulated Savannah River Plant Waste. USDOE Report DP-1507, Savannah River Laboratory, E. I. du Pont de Nemours and Company, Aiken, S. C. (1978). 
Figure 5 shows resistivity curves of Frit 411 glass measured by four investigators. Battelle Pacific Northwest Labs (PNL) and SRL curves were measured by the technique described in DP-1488. The method used by Owens-Corning Fiberglas (OCF) was not given. The SRL-TNX curve was measured with an operating, smal1-scale, electric melter. While the SRL-TNX curve is fairly close to the other curves, current density at an electrode can greatly affect resistivity. Therefore resistivities experienced in a large melter operating at high current densitles may be appreciably different from those measured in laboratory apparatus. 


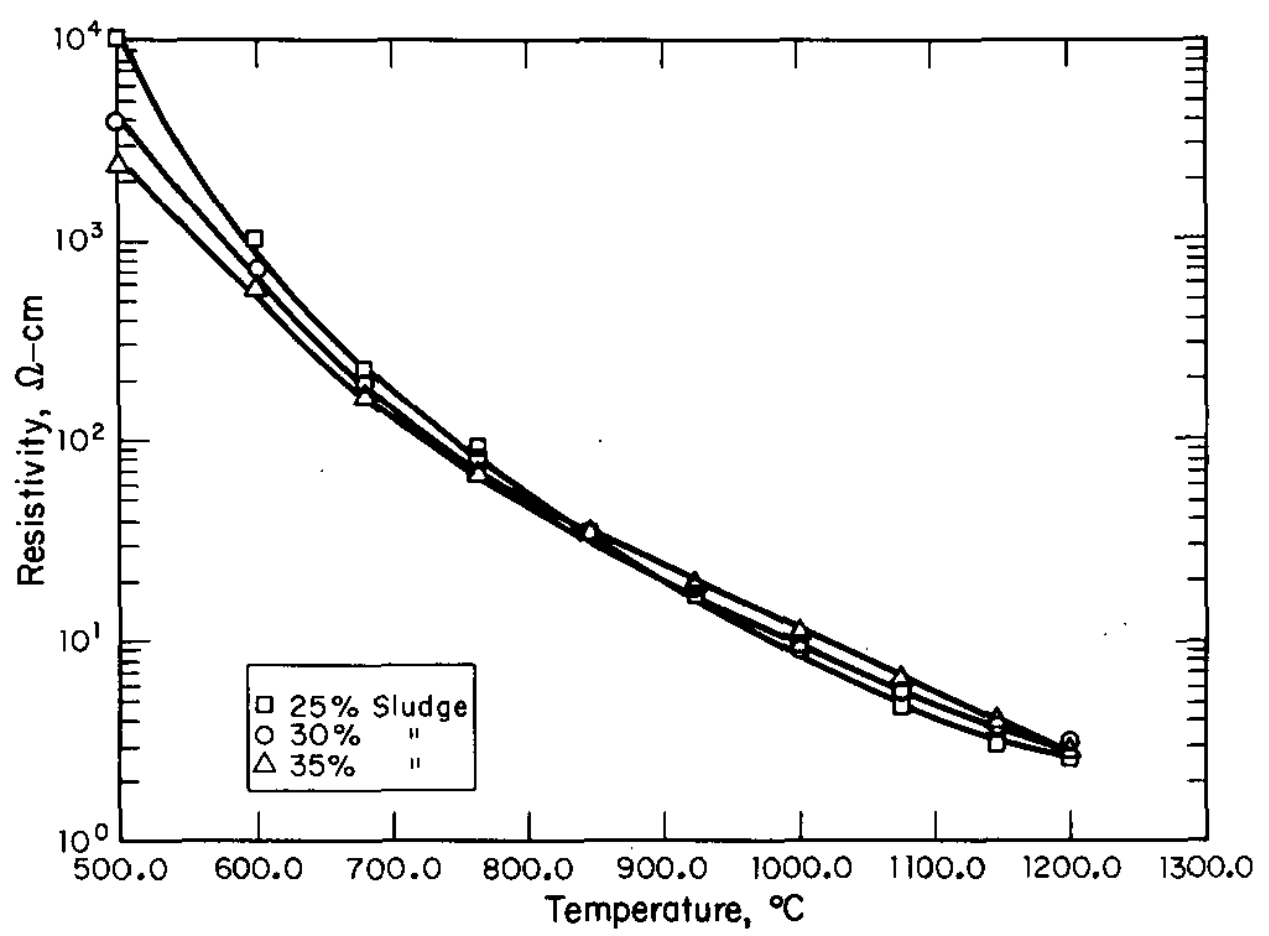

FIGURE 1. Resistivity of Frit 21 Melts Containing Composite Sludge

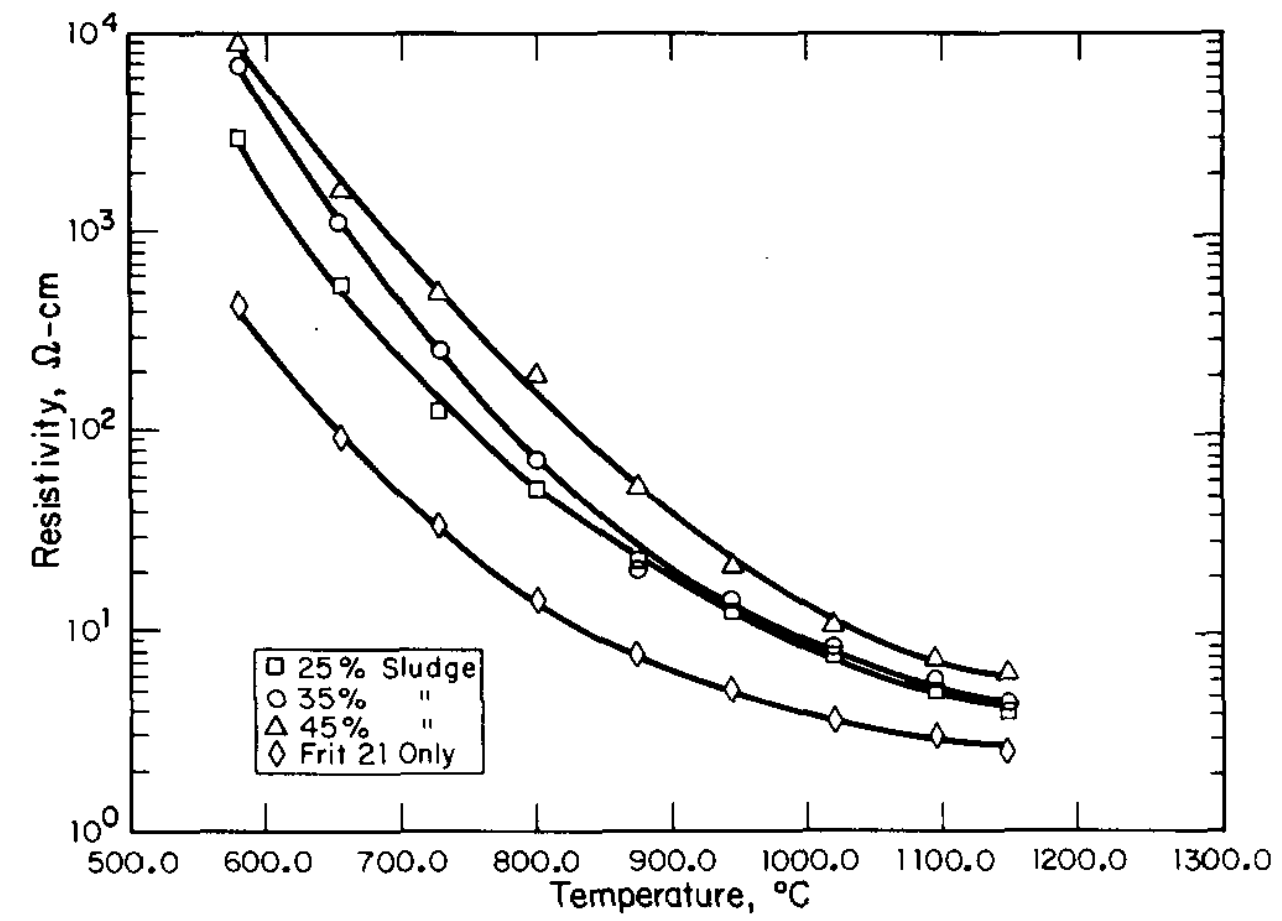

FIGURE 2. Resistivity of Frit 21 Melts Containing Average Sludge 


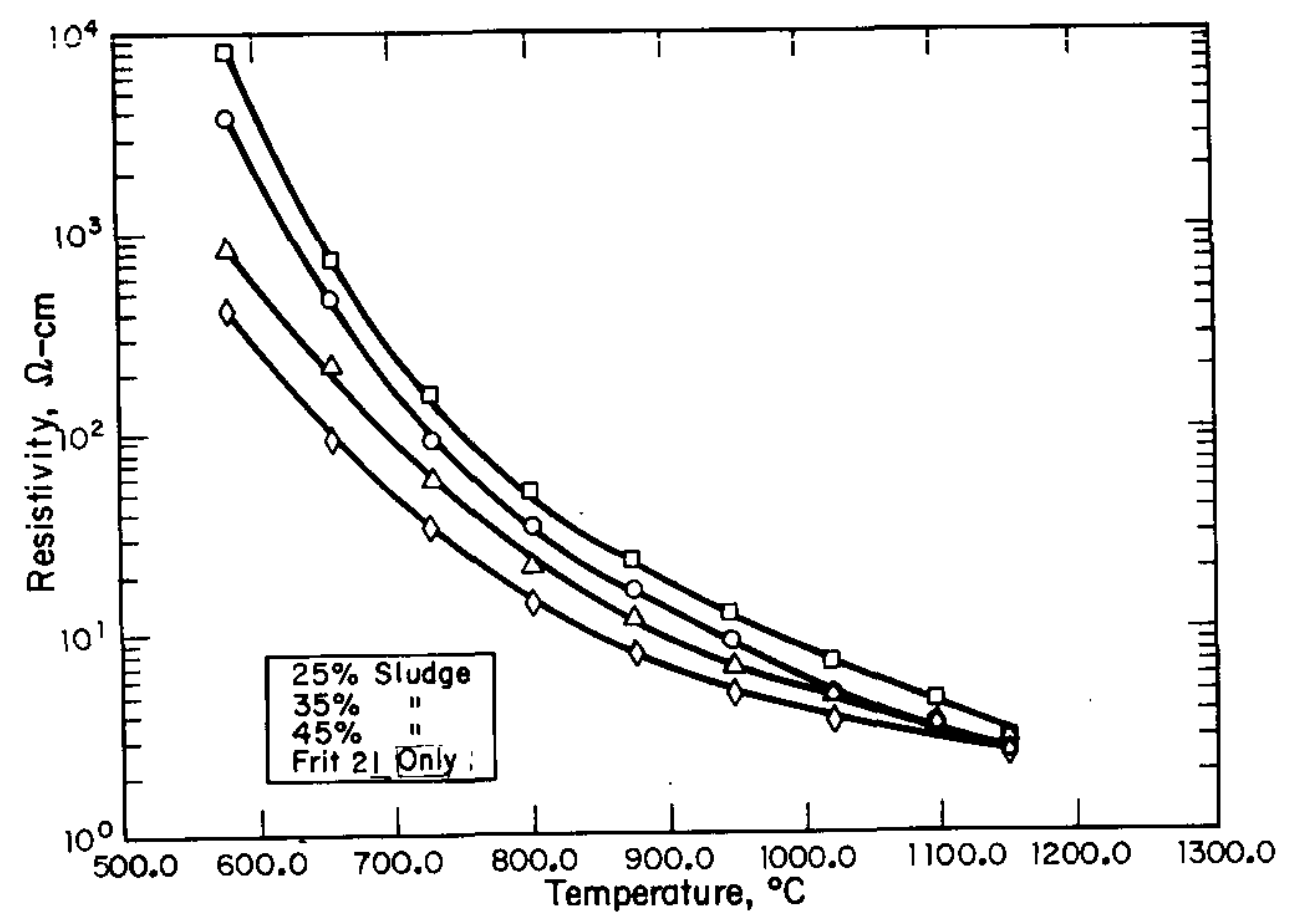

FIGURE 3. Resistivity of Frit 21 Melts Containing High-Iron Sludge

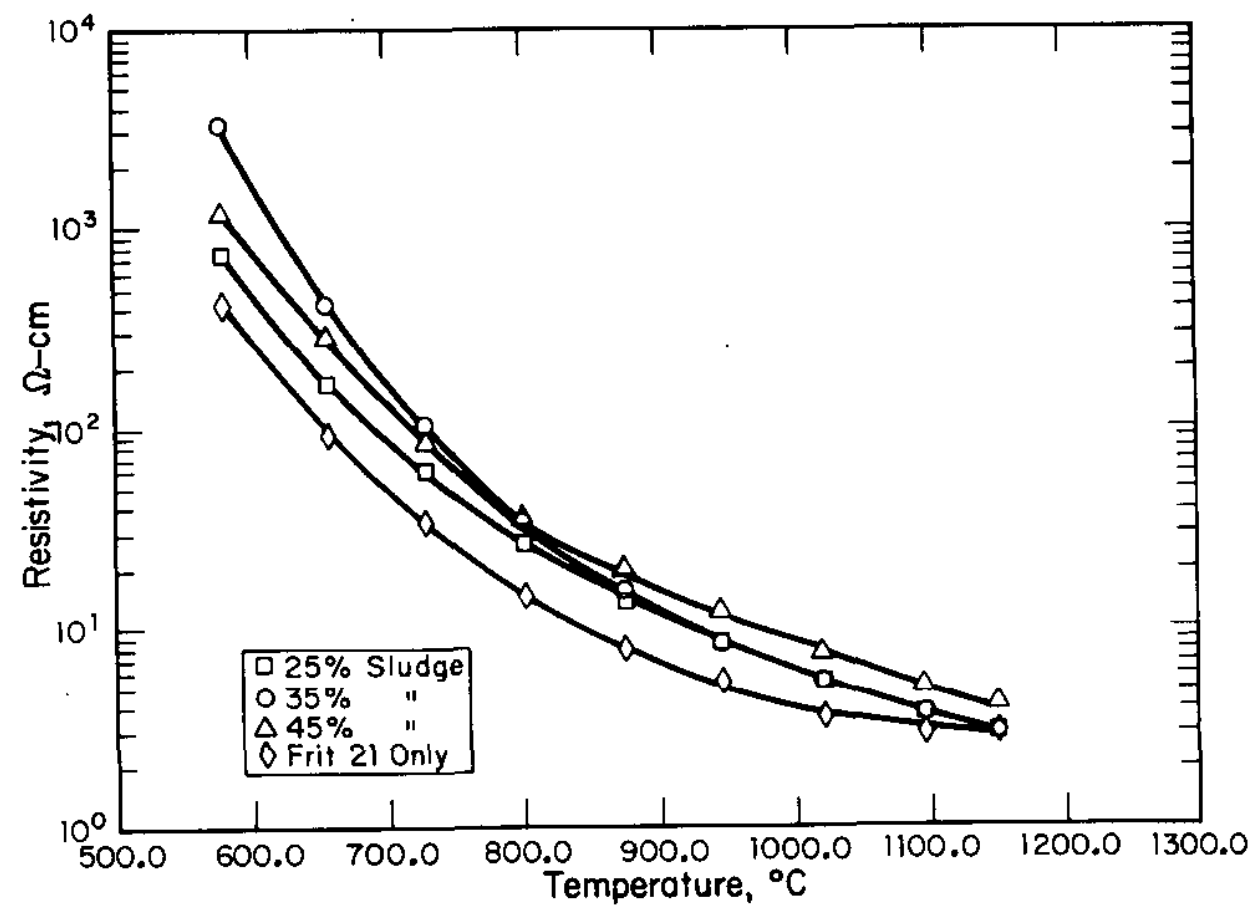

FIGURE 4. Resistivity of Frit 21 Melts Containing High-Aluminum Sludge 


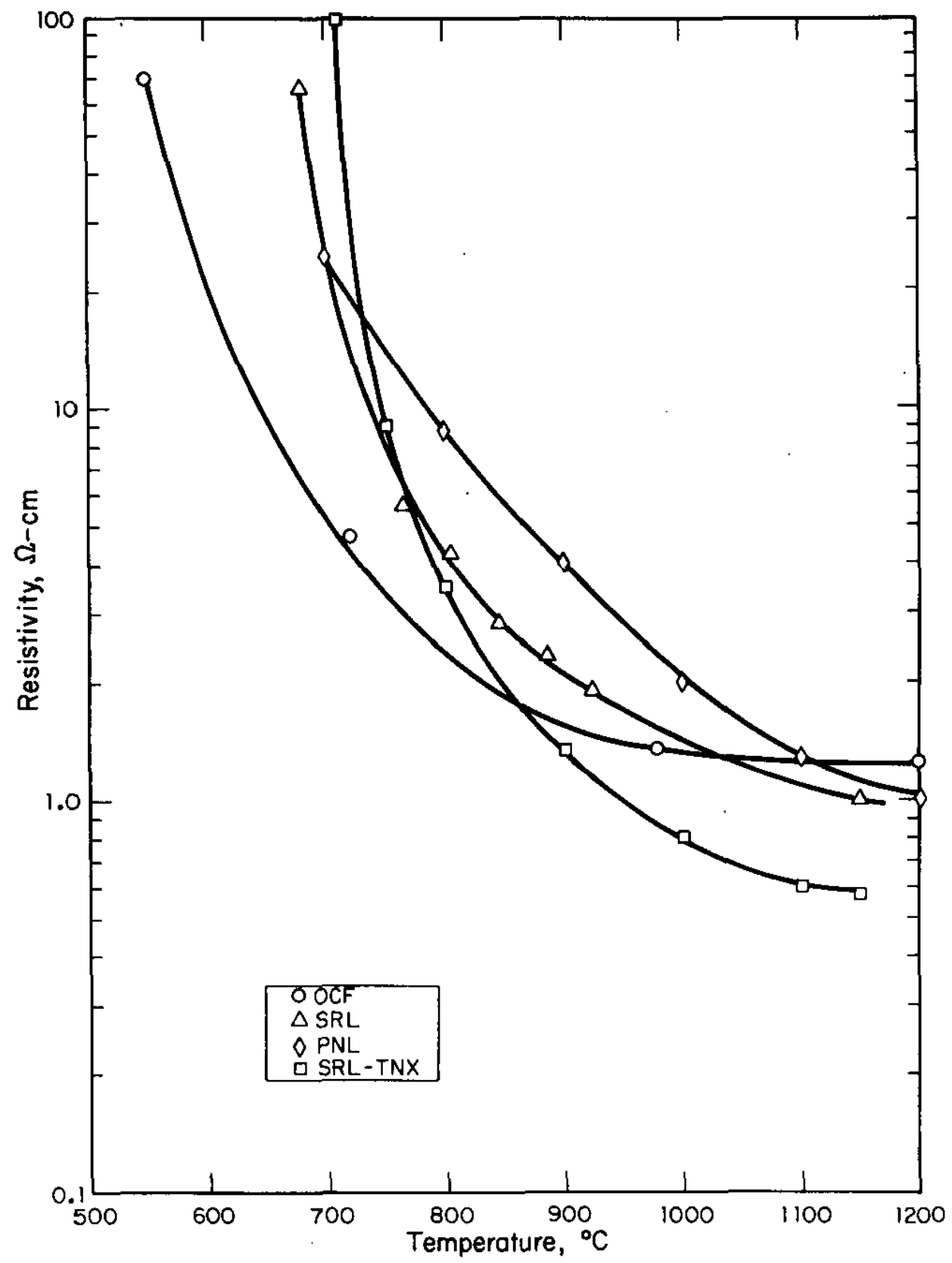

FIGURE 5. Resistivities of Pure Frit 411 Melts by Four Investigations 